\title{
FACTORS DISCOURAGING STUDENTS FROM SCHOOLING: A CASE STUDY AT JUNIOR SECONDARY SCHOOL IN LAOS
}

\author{
${ }^{1)}$ Chanthaboun Keoviphone; ${ }^{2)}$ Udik Budi Wibowo \\ ${ }^{1)}$ Vientiane Provincial Education and Sport Department, Laos; ${ }^{2}$ Yogyakarta State University, \\ Indonesia \\ ${ }^{1)}$ ckeoviphone@gmail.com; ${ }^{2)}$ yube2u@yahoo.com
}

\begin{abstract}
This study is aimed at exploring and describing the factors discouraging Laos students from schooling at a secondary school in various contexts such as classroom and school, individual student, family, and community contexts. Descriptive qualitative approach was used, and the framework of the study was formulated around the aspects of school and classroom situation, principal's management process, teachers' teaching organization and performance, parents' involvement and perception, and community's involvement and perception. The data were collected through observation, document analysis, and interview from 10 students, six teachers, one principal, one vice principal at Phonsyneua Junior Secondary School, and seven parents whose children were studying at this school. The finding shows that among the factors involved in students' schooling at secondary school, several factors discourage them. The teachers' performances were not perfect yet and some students' competency was not qualified enough. The students' parents were not highly committed and involved in their children's schooling. The community had little trust in schooling since they perceived that schooling costs a lot of money. To improve these discouraging factors, several actions should be taken into consideration. The principal should ask all the teachers to communicate the vision and missions to the students, or the vision and mission should be published and socialized in the school. The observations on teachers' instruction should be done by both the principal and senior teachers.
\end{abstract}

Keywords: classroom and school context, individual student, family, community 


\section{Introduction}

Laos or the Lao People's Democratic Republic (Lao P.D.R) is a small landlocked country, but now it becomes the land-link country for ASEAN countries transport of goods such as Thai, Laos, Myanmar, Vietnam, Cambodia and China. The eradication of mass poverty becomes the current major goal of Lao government. Basically, there are four fundamental sectors which are concentrated by national development goals such as agriculture and forestry, education, health and road infrastructure. In addition, educational development is very important for Lao, focusing on educational problems such as the general conditions of inequity in access to schooling, inefficiencies in students' progress through school, and the low quality of instruction-conditions policy.

Moreover, Laos students are still considered as lack of creativity and original thought, so that the outcome of teaching and learning process in Lao primary and secondary schools tends to be negative. This might emerge due to the teachers' behavior and teaching style. Furthermore, the size of Lao schools still becomes consideration in such small municipalities with limited resources, in which it creates new difficulty in offering comparable supportive functions. This might become a reason of the poor outcome of teaching and learning process. Currently, teaching and learning method still focuses on the situation or setting of the school location, especially in the schools located in remote areas. The teachers do not have a chance to train and gain new ideas and new techniques/ curriculums, therefore, the teaching quality is poor. Besides, it will also produce impact to Lao students' quality and learning outcome.

The Seventh Lao People's Revolutionary Party Congress in 2001 and the Lao People's Revolutionary Party Congress in 2006 also emphasized that human resource development depends on education reform leading to a better quality basic education, equivalent to other countries. The government has given priority to education, considering that it is a key element of human resource development policy. Education is one of the top priority sectors contributing to poverty eradication. The quality of Laos basic education is very low if it is compared to the neighboring countries. These issues emerge due to many factors which affect the quality of basic education, in which one of the most important factors is teachers' quality. Because there are many unqualified teachers, thus, Lao education finds it difficult to develop into standard level like other countries and is incapable to reach the Millennium Development Goals (MDG). The development of the curriculum and teachers' qualification are the main aims to manifest educational development and also reduce the drop out and repetition rates.

Lao educational system goes through the levels from Kindergarten and pre-school (3years); Primary education (5 years); Lower secondary education (4 years); Upper secondary school (3 years); Vocational and higher education (2-4 years); Undergraduate level (4-6 years); to Master degree (2-5 years), research and Doctor of Philosophy (PhD) (up to 6 years), depending on the field of study. There are still some remaining issues in Lao's education, for example, about $11 \%$ school-age children leave school due to some conditions, such as living in small or isolated village so that they have difficulty to reach the school in town. Some of the students also get difficulties because of the distance from their homes to school. In addition, poverty keeps Lao people away from education. This condition is worsened by the local culture to conserve, such as the paradigm that girls should be kept at home and get married at early age. This paradigm leads to the less awareness of the importance of education in Lao. Other educational problems which emerge in Lao are related to the high number of drop out rate in grade 1 and 2 , the absence of pre-primary school in the rural areas, indigene children's reluctance to speak using national language, the shortage of local teachers, qualified teachers, and male teachers, and also the shortage of teaching and learning materials. 
According to the current Phonsyneua Junior Secondary School principal, Mr. Sithon, there were five drop out students and ten students who left the school before completing lower secondary school in 20092010. In 2010-2011, there were three students who were dropped out and six students who left the school before completing lower secondary school. In 2011-2012, there were two drop out students and five students who left the school before completing lower secondary school. In 2012-2013, there were no students who either left school or were dropped out, but four male students could not pass the examination. They were one student of grade 6 and grade 7, and two students of grade 8, so they still studied at the same grade.

\section{Method}

Type of the Research

Qualitative research case study was used in this study since the focus of this research was attempted to answer the questions of 'why' and 'how'. 'Why' questions would be relevant to why the students drop out from school, why the students are not highly motivated to finish their secondary schooling after leaving primary school. 'How' questions would be related to how the teachers organize and perform the teaching and learning processes in the classrooms, and how the students' parents and community get involved in children's education at secondary school. In this qualitative research, the researchers used subjectivity to draw a conclusion of the particular cases which they had already observed. They also analyzed and described the document collected by using their own judgment. Hence, they typically observed, interviewed and analyzed the data obtained from the research field.

Using case study for research purpose is one of the most challenging methods of all social science endeavors. The purpose of case study method is to help researchers, experienced or budding social scientists to deal with the challenge. The researchers' goal was to design a good case study and to collect, present, and analyze data fairly. The case study as a research method (Yin, 2009, pp. 2-164) is explained as follows:

Plan

In planning the research, some steps were done by the researchers: Identifying research questions or other rationale for doing a case study; deciding to use the case study method; comparing to other methods; and understanding its strengths and limitations.

Design

In designing the research, some stages were passed: Defining the unit of analysis and the likely case(s) to be studied; developing theory, propositions, and issues underlying the anticipated study; identifying the case study design (single, multiple, holistic, embedded); defining the procedures to maintain case study quality.

\section{Prepare}

Some important steps were taken in preparation stage: Honing skills as a case study investigator; practicing/training for specific case study; developing case study protocol; conducting pilot case; gaining approval for human subjects' protection.

\section{Collect}

In collecting stage, the researchers had to pass some steps: Following the case study protocol; using multiple sources of evidence; creating case study database; maintaining the chain of evidence.

\section{Analyze}

In analyzing stage, some steps were conducted: Relying on theoretical propositions and other strategies; considering any of five analytic techniques, using quantitative or qualitative data or both; exploring rival explanations; displaying data apart from interpretations.

\section{Share}

Some steps were conducted in sharing stage: Defining audience; composing textual and visual materials; displaying enough evidence for reader to reach own conclusions; reviewing and re-writing until it is done well. 
Place and Time of the Research

The research was conducted at Phonsyneua Junior Secondary School in Phonhong District, Vientiane province, Laos. This research was held from January to March 2014 to gather the data and make analysis to complete the research study on the factors discouraging students from schooling, which made them drop out without finishing their secondary education.

Subjects of the Research

The subjects of this study were the factors discouraging students from schooling. Data and information were provided by the school principal, vice principals, teachers, and students in the typical junior secondary school: Phonsyneua Junior Secondary School in Phonhong district, Vientiane province in Laos. The students were selected to be asked about their schooling plans, their teachers' performance, and their reason for dropout from school, whereas the teachers were selected to be interviewed about their teaching performance, the students' performance and competency, and the reason of students' dropout from school. Furthermore, the principal and vice principals were asked to give information about what they had done in their management process to reach students' high achievement. The students' parents living in the villages surrounding the location of the school were asked to give information relevant to their involvement in their children's schooling and their perceptions about schooling. Those who had fairly high standard of living acted as the community.

\section{Data Collection Techniques}

There were three methods used in this study: observation, interview, and document analysis. These three methods were formulated around the framework of school situation, students' dropout rate, teachers' instructions, students' motivation, and parents' and community's involvement in the students' schooling at secondary school.

The observation involved the researchers in observing how the school principal, vice principals, teachers, and students acted and how things at school looked, and they recorded the events. Interview was used to check the accuracy of the impression they had gained through the observation; to find out what was on the key and sub informants mind or how they feel about something. Document analysis was the analysis of the documents' written or visual contents, such as newspaper, journals, reports, and letters which were greatly valueable to the research. Furthermore, the information that might be impossible to obtain through direct observation can be gained through analysis of available communication materials.

\section{Research Finding Criteria}

The finding of this study was planned to be segmented into four categories, namely: classroom and school context, individual student context, family context, and community context. These contexts either affected or were affected by one another.

\section{Data Credibility}

To ensure the data credibility, there are some strategies which were employed. The strategies are listed below:

\section{Triangulation}

Triangulation was achieved by employing various instruments: observation, interview, and document analysis.

\section{Informant Checking}

Informant checking involved checking an informant's descriptions of something compared to another informant's descriptions of the same thing.

\section{Recording}

Recording dealt with recording the researchers' own thoughts as they went through their observations and interviews. Responses that seem unusual and incorrect could be noted and checked later based on other remarks or observations.

\section{Mechanically Recording the Data}

Recording the data mechanically was achieved by using tape recorder, photographs, and videotapes. 


\section{Low-inference Descriptors}

Low-interference descriptors involved recording precise, almost literal, and detailed descriptions of people and situations.

\section{Participatory Modes of Research}

The informants would be involved in most phases of this study, from the beginning of the data collection until checking interpretations and conclusions.

Data Analysis Techniques

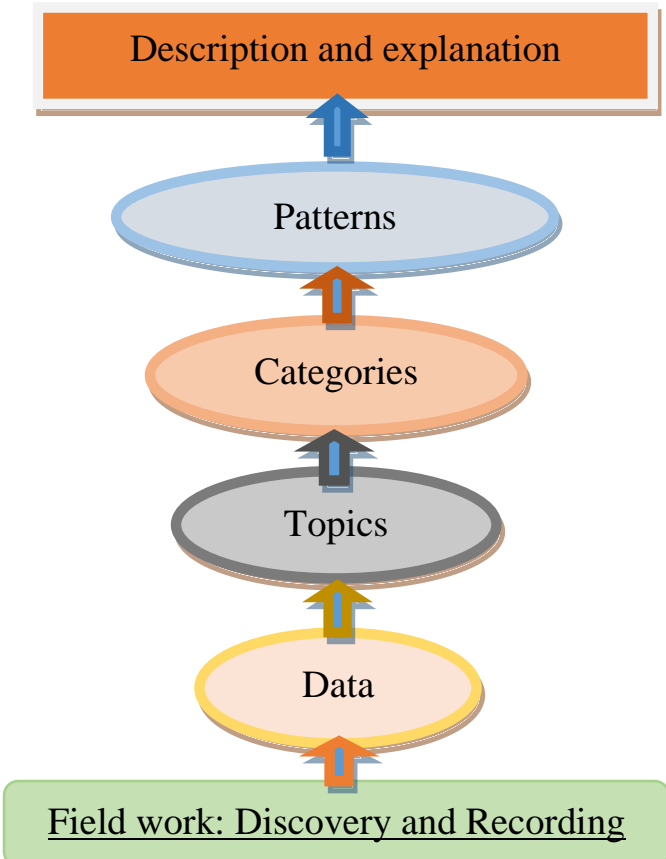

Figure 1. Process of data analysis (Adapted from McMillan \& Schumacher, 2001, p. 463)

Analyzing data in a qualitative study essentially involvs collecting the information obtained by the researchers from various methods such as observation, interview, and document analysis into a coherent description of what the researchers had collected or discovered. With this regard, the technique of collecting was used during the analysis. After the researchers obtained the data, they identified the data segments and named a topic. Then, the researchers grouped those topics into a larger cluster to form the categories. As the researchers developed categories, they looked for the patterns or relationships among the categories to see how they either affected or were affected by other categories. In searching for patterns, the researchers tried to understand the complex links between the various aspects of informants' situations, beliefs, and actions. Consequently, analysis is an ongoing process which may occur through a research.

\section{Findings and Discussions}

Phonsyneua Junior Secondary School is one of the state schools in Laos which has been providing free secondary education tuition in every academic year for Laos students. The prior name of this school is Sisattana Junior Secondary School. It was located in Ban Saensa-Arth, Phonhor campus. This school was built on 1 September 1975 and was built in an area surrounded by 6 villages and 899 houses including Lao-kang (Middle Land) 14 houses. There were 1027 families: 5121 people with 2382 women, and 14 families of Lao-kang (Middle Land): 127 people with 62 women. The principal in that year was $\mathrm{Mr}$. Visay Keomahavong. There were 8 teachers which taught grade 6-8 students. In 19761977, when Mr. Bounyang Chanthavong was the principle of the school, the school was broken because of the storm so the students were moved to study at Phonkeo Primary School. In 1977-1978, the principal was Mr. Sibay Visatheb and after this year he went to Vientiane Capital city to continue his study there. From 1978 until now, the principal is Mr. Sithon Chanthabouly.

In 1975-1982 there were students of Phoupha campus who studied in Silattana Junior Secondary School. In 1982-1983, this school was divided into two: the first school was still in Ban Phonkeo with the same name, and the second school was in Hinherb district and the name was Konkeo Junior Secondary School, but it was run under Silattana Junior Secondary School. Thus, the education materials for both schools were not sufficient since they still used education materials from Silattana Junior Secondary School.

In 1985-1986, Khonkeo Junior Secondary School became an independent school, so Silattana Junior Secondary School was changed to Phonsyneua Junior Secondary School until now. On 22 July 
1997, this school had new building built by the inhabitants in that area with the budget more than nine million dollars. There are two buildings in this school: The new twofloor building and the old one-floor building.

Phonsyneua Junior Secondary School was located next to the $13^{\text {th }}$ Northern Road, and the school buildings are located about 50 meters from this road. Its area is 910 square meters, and the school number is 005 (got this number in 2008). In 2009-2010, there were grades 6-9; grade 6 had 74 students with 35 women, grade 7 had 66 students with 36 women, grade 8 had 62 students with 29 women, and grade 9 had 59 students with 31 women, so the total students were 261 with 131 women. In 2010-2011, there were 275 students with 135 women; grade 6 had 89 students with 31 women, grade 7 had 69 students with 34 women, grade 8 had 60 students with 33 women, and grade 9 had 57 students with 27 women. In 2011-2012, there were 305 students with 140 women; grade 6 had 81 students with 31 women, grade 7 had 90 students with 41 women, grade 8 had 72 students with 33 women, and grade 9 had 62 students with 35 women.

Based on the observation in Phonsyneua Junior Secondary School, there are some points to be noticed. The first point is about the school's physical building and facilities. The school is located near the $13^{\text {th }}$ Northern road and the school is about fifty meters from the $13^{\text {th }}$ Northern road. It is shared with Hinherp district in the north, Phonhor campus in the south, LongLeek campus of Keo-Oudom district in the east, and Nasam campus of Hinherp district in the west. The school consists of two buildings with fifteen rooms. There are eleven rooms used for teaching and learning process, a room functioned as a store as well as a library, and a room for school principal and teachers, and it is separated into two parts. There is a library with 10 computers donated by Korean charity. In each class, there are wooden desks for students with the following details: 14 desks for grade 6; 15 desks for grade 7; 12 desks for grade 8; and 11 desks for grade 9. In addition, there are a desk and a chair for the teacher, and a blackboard on the wall in front of the classroom, and a piece of paper stuck near the blackboard written about the classroom sweeping groups.

The second point is that when the observation was conducted, there was a notice board in the office informing that there would be a meeting on Friday at three o'clock. There was another notice board in front of the office informing about some news and scholarships. Further, the third point is that there are no photos of academic students' yearly excellent achievement stuck on the notice boards.

Finally, the fourth point is about the teaching and learning process in the school. Most teachers have lesson plans for their teachings so that the teaching and learning process in the classrooms is conducted as follows: (1) The teachers explain the purpose of that lesson; (2) ask the students to note or write the important things from that lesson; (3) ask the students to make groups; (4) give them some questions; (5) let them answer or do; (6) let them copy the answer if it is already correct; (7) deliver teaching and learning materials; (8) evaluate the students.

Meanwhile, some teachers do not have the lesson plans for their teachings so that the teaching and learning process in the classrooms for some subjects is conducted as follows: (1) checking the students' presence; (2) asking several questions about the lesson taught in the previous session; (3) explaining the new lesson; (4) asking the students to work in groups to do the task; (5) checking the answers with the whole class; (6) doing the comprehension check; (7) giving advice and homework; (8) saying good bye.

Muijs \& Reynolds (2005, pp. 107-108) have suggested that school climate will strongly influence classroom climate, and in order to be effective, the two need to be complementary. They have also revealed that most studies have identified classroom climate as an important concomitant of pupil achievement. Therefore, it can be said 
that the school and classroom climates at Phonsyneua Junior Secondary School can be regarded as influential factors for the supporting students' achievements since its location was handy and secure.

Bush \& Coleman (2000, p. 10) have supported that a strategic approach to management requires an explicit sense of direction and purpose, and defining a clear vision for the organization is an important stage in this process. Consequently, it can be concluded that Phonsyneua Junior Secondary School which is one of the state schools providing Lao students with secondary education has a clear purpose since it has its own vision and mission. These vision and mission can be used to improve the teaching and learning processes. As a result, the students' high achievements are able to be attained at the end of the academic year if they were implemented well.

Davis \& Thomas (1989, pp. 22-23) have suggested that through daily interactions and modeling, the principal transmits his or her vision of a better school to teachers and other staffs and influences them to act to achieve that vision. Thus, it can be inferred that although Phonsyneua Junior Secondary School had already formulated the vision and mission to help the Ministry of Education in Lao to achieve the long-term mission, it did not succeed in helping the ministry of education, or it was not able to provide the students with much benefit from the vision and mission because the vision and mission were not well implemented. During the interviews, only two of five teachers knew the school's vision and mission, while others did not. Seven out of eight students told that they did not know and understand well about the school vision and mission. Therefore, they did not know what they could do to help the school to achieve its vision and to help the ministry of education accomplish her/his long-term mission. Thus, the teachers should inform the students about the school's vision and mission before they start teaching on the first day.
Roe \& Drake (1974, p. 227) have illustrated that evaluation is essential to the continuous improvement of the life quality of each individual within the school, including both pupils and teachers. Thus, it can be seen that the school principal at this school had done one thing in the right track of the good principalship, but on the other hand, he evaluated the teachers with the lack of authentic information because he rarely observed the teaching and learning processes conducted by the teachers in the classrooms.

Davis \& Thomas (1989, p. 18) have identified that effective principals in successful schools observe teachers in the classrooms and provide positive, constructive feedback aimed at solving problems and improving instruction. Hence, it can be described that the school principal at this school should be considered as effective to handle teachers and students more.

Sallis (1993, p. 128) has revealed that staff development can be seen as an essential tool to build quality awareness and knowledge, and it can become a key of strategic change agent for developing quality culture. According to the afore-mentioned research finding, although all teachers at this school were regarded as being qualified not only by the school principal but also by the students, the training and staff development were still conducted at this school monthly to improve the teachers' quality. With this regard, the teachers were required to join the monthly meetings first. After the monthly meetings had finished, they were required to join different group discussion depending on the subjects because there was a head for each subject.

Hoy \& Miskel (2008, p. 380) have supported that goal-directed behavior is elicited through communication; hence, the greater the clarity and understanding of the message, the more likely the administrator, teacher, and students actions will proceed fruitfully. As mentioned on the finding, it can be inferred that there was a lack of guidance from teachers for the students at this school, which could be used to guide 
the students to do their best towards the intended purposes. From the observation, it was shown that although there were two notice boards which were used to provide information, there was only little information of what to guide for the students to accomplish their high achievements in their educational lives. This made students do not know what to do to help the school to achieve the its purposes clearly. In addition, if much information used as the guidance was communicated well to the students, it would help them all to prepare themselves for their upcoming futures. As a result, they would be highly committed to their studies. Thus, teachers could assist in guiding the students to do their best towards the intended purposes.

Woolfolk (2007, p. 399) has suggested that students should be encouraged to improve their own personal ability, perform difficult tasks, keep persistence, and be creative. Consequently, it can be concluded that the school principal at this school pays attention to the students' improvement of their academic achievement. Although there were no photos of the moments of giving the honorary awards for the students' academic achievement or any awards in the office stuck on the notice boards when the observation was conducted, it was known from the interviews that honorable mention certificates were given to the students for their achievements in an academic year. To do this, the school principal collaborates with the classroom teachers to encourage the students' accomplishment by providing the top-three students in each class with the honorable mention certificates in their own classrooms by their classroom teachers at the end of each academic year.

Borich (2000, p. 351) has suggested that establishing rules and procedures to reduce the occurrence of classroom indiscipline problems will be done as the most important classroom management activities, especially at the beginning of the academic year. Thus, as mentioned in the finding, it can be inferred that the teachers' first day teachings at this school were not considered good yet because four out of five teachers just introduced their names to the students, asked the students to write their short family background, and such activities on their first day, without establishing the rules and procedures of the teaching and learning processes in the classrooms for the whole academic year. They did not tell the students what they were going to learn, from when to when, and what they needed to do during each semester. In addition, they did not introduce the school vision and mission to the students, nor did they set up the performance standards to help the school accomplish its vision. Thus, the teacher should establish the rules and procedures of the teaching and learning processes in the classrooms for the whole academic year.

Orlich, Harder, Callahan, Trevisan, \& Brown (2007, p. 64) have illustrated that the more systematic your instructional planning is, the greater the probability that you will succeed,. Planning instruction or lesson means establishing priorities, goals, and objectives for the students. Therefore, it can be concluded that although they had the teachers' book used as the guidance for their instructional activities, the teachers' preparation for the teaching and learning process in the classrooms at this school is still regarded as being useful to make the teaching and learning processes more effective since the finding reveals that most teachers taught their students with the lesson plan preparation, while some others used the teachers' guidance without the lesson plan preparation. Planning the lesson before teaching is very important for the teachers because it can make the teachers know what they have to do during the teaching and learning process in each session.

Davis \& Thomas (1989, p. 123) have suggested that some factors contributing to active teaching and maintaining a brisk pace include starting class quickly and purposefully, and also ending lessons promptly. They also reveal that the teacher can use clear start and stop cues to help the lessons run according to the specific time targets. Based on this reason and aforementioned finding, it can be concluded that 
the teaching and learning processes conducted by a few teachers at this school were not regarded as good instructional activities although most of the teachers' instructions are acceptable. The interviews with the students showed that a few teachers were not punctual in teaching - they came late to teach and leave the class early, and a few of them did not come to teach their students regularly. Thus, the teachers should come to teach punctually and regularly.

Orlich, Harder, Callahan, Trevisan, \& Brown (2007, p. 18) have identified that teacher can teach only if the learner has desire to learn, known as motivation. Hence, according to the finding, it can be seen that the students at this school had desire to learn; in other words, they had motivation as it is revealed in the interview that they plan to finish their study at secondary school and pursue their higher study in university. They believed that by doing this, they would be able to become good citizens with good reputation and glory in the society. Because the students had motivation for their studies, it can be concluded that the teachers at this school found it easy to conduct the teaching and learning processes in the classrooms if they had willing to do their best for their teachings.

Lefrancois (2000, p. 421) has illustrated that competence motivation is manifested in the struggle to perform competently, the feelings of confidence and worth that comes along with successful performance. Consequently, from the result of the interview, it can be seen that some students studying at this school were not qualified enough to start their secondary education yet because in the interviews, the teachers commented that some students could not even read and write some words correctly, and they, the students, seemed to have difficulties in following the lesson which was taught in each session. As a result, the teachers found it hard to teach them as well, and these students are risky for dropping out of the school. Thus, the students should be qualified enough to start their secondary education.
Muijs \& Reynolds (2005, p. 86) have revealed that schools in regional areas are likely to suffer from students' misbehavior. Therefore, a disciplined, structured and caring environment needs to be provided in order to help compensating for what students are missing at home. From the aforementioned finding, it can be said that it is not hard for the school to correct the students' misbehavior or to help compensating what the students are missing at home since they are good students because the interviews with both school principal and teachers showed that most of the students were obedient. They tried to listen to their teachers while their teachers were explaining the content of the new lesson to them. However, there were still only very few students who had misbehavior. To solve this problem, the school principal has to work together with the teachers to correct the students' misbehavior by endorsing them with the knowledge of school regulation and educated advice.

Woolfolk (2007, p. 76) has identified that parenting that is strict and directive, with clear rules and consequences combined with high levels of warmth and emotional support, is associated with higher academic achievement. Hence, based on the research finding, the parents whose children were studying at this school lack the state of being strict and directive with clear rules because they rarely monitored their children's schooling. With this regard, they thought that they did not have sufficient ability to explain to their children what were taught at school. In contrast, they still provided their children with the warmth and emotional support since during the interview they commented that they tried to provide their children with emotional and financial support. Hence, the parents whose children were studying at this school should be the state of being strict and directive with clear rules and also provide warmth, emotional and financial support for their children.

Ormrod (2003, p. 131) has illustrated that students' school performance is correlated with socioeconomic status; 
students with higher socioeconomic status tend to have higher academic achievement, and students with lower socioeconomic status tend to be at greater risk for dropping out of school. Consequently, it can be seen that the low socioeconomic status of the students' parents tended to produce greater risk for the students' performance at school because in the interviews with students' parents, they thought that they needed to invest a lot of money on their children's secondary education as well as higher education. They believed that although their children finished their secondary education, they still found it hard to get a job. In addition, because of their economics priority, they had to ask their children to quit their study and find a job to help their family in earning money.

Ormrod (2003, p. 505) has suggested that students whose parents are involved in school activities have better attendance records, higher achievement, and more positive attitudes toward school. Thus, according to the above-mentioned research finding, it can be concluded that there was lack of students' parents' involvement in their children's schooling at this school since the research finding shows that the students' parents do not have any relationship with the school principal as well as the teachers of the school where their children were studying. Therefore, they have only little ideas of what is going on with their children's schooling, and it leads to the lack of corrective actions for their children's schooling.

Mohrman, Wohlstetter, \& Associates (1994, p. 84) have suggested that effective school has positive relationships with the community it serves, and it is regarded as a member of the community it serves. The sense of community helps reducing alienation between the school and the community and increasing students' achievement. Therefore, there is a community involvement because in the interview, the school principal told that the community where this school serves helped the school by providing some tables and spaces to fill some parts of the school building. However, it was just a little involvement in children's schooling. Thus, the community should be involved in higher involvement in this school for increasing students' achievement.

Hoy \& Miskel (2008, p. 191) have revealed that trust in schools is important because it facilitates cooperation, enhances openness, promotes group cohesiveness, and improves students' achievement. Consequently, it is known from the interview that the community believes that education is very important for their children. They can see that higher-educated people could find good jobs easily. However, it can also be concluded that there is a lack of trust from the community towards secondary education and higher education since they reveal that they need to spend a lot of money on the education for their children.

\section{Conclusion and Recommendation}

Conclusion

Based on the research finding and discussion, the four contexts involved in students' schooling have performed their tasks well in several ways, whereas some aspects of their performance still need improvement to motivate the students for schooling. Therefore, the conclusion of factors discouraging students from schooling at this school can be drawn as follows:

First, some positive aspects of controlling are conducted at this school. However, planning and controlling the teaching and learning processes are not good because of the following causes: (a) Yearly evaluations towards the teachers' performace at this school are conducted with the lack of authenticity and transparency, (b) monthly technical meetings for staff training and development at this school are not conducted on the most effective dates, (c) the information which is communicated to the students as the guidance for their academic lives at this school is still limited, and (d) the ways of giving the honorable mention certificates to the top-three students are not done on the 
most effective dates to motivate the students for schooling.

Second, although the teachers have performed their instructional activities well in some aspects, other aspects need to be improved because: (a) Most teachers do not set the performance standards for the teaching and learning process on the first day of their teachings, (b) some teachers do not have lesson plan preparation for the teaching and learning process, (c) a few teachers are neither well-prepared nor punctual for their teachings, and (d) a few of them do not come to teach their students regularly as the arranged schedule.

Third, the students who are not highly motivated for their schooling are not qualified enough for their secondary education. Fourth, although the students' parents support their children with emotional and financial supports for schooling, they still have some jobs that they do not perform well in a few ways: (a) They rarely monitor their children's schooling, (b) some parents regard family's socioeconomic status as the first priority rather than their children's schooling because of poverty, and (c) they do not have close relationship with the school where their children are studying.

Last, even if the community gets involved in the students' schooling by helping to improve the school's campus and repair the tables and chairs, it has little responsibility or little involvement in the students' schooling at secondary school. Although the community perceives that schooling is very important for children, they do not have much trust in it since they state that they spend a lot of money on it.

Recommendations

According to the afore-mentioned conclusion, several recommendations are shared as follows:

First, it is recommended that the implementation of planning and controlling the teaching and learning process at this school should be improved. To do this, several actions should be taken: (a) The vision and mission should be communicated to the students on the first day of the teachers' teaching performance, (b) the formal observations streamlined into three phases such as pre-observation conference, classroom observation, and post-observation conference on the teachers' teaching management should be done by senior teachers, (c) yearly evaluations for the teachers should be done by the school principal and other evaluators more authentically and transparently by using the information notes from the observations and they should ask the teachers to sign for their acceptance of the results before being sent to the provincial education department, (d) monthly technical meetings for the staff training and development should be conducted on Mondays so that all teachers can attend the meetings, (e) more information about academic guidance should be communicated to the students, and $(\mathrm{f})$ the honorable mention certificates given to the top-three students of each class should be done on the opening ceremony day.

The second recommendation is that the teachers should make more contacts with the students' parents by sending them invitation letters to discuss their children's schooling. Third, it is recommended that several aspects of teachers' teaching management should be enhanced, and to achieve this, the teachers at this school should do the following tasks: (a) On the first day of the teaching and learning process, the teachers should provide syllabus for the students and set up the rules and procedures for the teaching and learning processes, (b) all teachers should be either well-prepared or punctual for their teachings, and (c) all teachers should come to teach the students regularly.

Fourth, students' low competency should be more focused. To do this, the classroom's teacher should invite the students with low competency to come to his/her office and talk directly and personally to find out their difficulties and ask other teachers to help them during the teaching and learning processes in the classrooms. In addition, the information of those low-competency students should be 
communicated to their parents so that they can help the school to improve their children's learning competency.

Fifth, the students' parents should do more important tasks for their children's learning: (a) They should monitor their children's schooling regularly, and they should also go to school to meet the teachers to ask about their children's schooling as often as possible, (b) they should regard their children's schooling as the first priority. To change this perception, they should be invited to attend the opening ceremony so that they can have chance to listen to the explanation on how important education is for their children, and they know how to help their children for schooling. As a result, they will do their best for it, and (c) they should have close relationship with the school. Thus, they should come to school to ask about their children's schooling with the teachers more often.

Sixth, the community should get involved more in students' schooling. They should be invited to join the opening ceremony every new academic year, and be informed by the principal about what is going on at school monthly so that they can share more responsibility for the students' schooling.

Last, the value of trust in students' schooling should be taken into account. To do so, the teachers should strengthen the students' discipline. If discipline is strengthened, the teachers and students will be highly involved in the teaching and learning processes. As a result, the quality of education will be improved, and trust can be built as well.

\section{References}

Borich, G. D. (2000). Effective teaching method. London: Prentice Hall, Inc.
Bush, T., \& Coleman, M. (2000). Leadership and strategic management in education. London: Paul Chapman Publishing Ltd.

Davis, G. A. \& Thomas, M. A. (1989). Effective schools and effective teachers. Massachusetts: Library of Congress Cataloging-in-Publication Data.

Hoy, W. K. \& Miskel, C. G. (2008). Educational administration: Theory, research, and practice ( $8^{\text {th }}$ ed.). New York, NY: McGraw-Hall International Edition.

Lefrancois, J. Y. R. (2000). Psychology for teaching. Belmont: Thomson.

McMillian, J. H. \& Schumacher, S. (2001). Research in education: A conceptual introduction. New York: Longman.

Mohrman, S. A., Wohlsletter, P., \& Associates. (1994). School-based management. San Francisco: JooseyBass Publishers.

Muijs, D. \& Reynolds, D. (2005). Effective teaching: Evidence and practice. London: Sage Publication Ltd.

Orlich, D. C., Harder, R. J., Callahan, R. C., Trevisan, M, S., \& Brown, A. H. (2007). Teaching strategies: A guide to effective instruction. New York, NY: Houghton Mifflin Company.

Ormrod, J. E. (2003). Educational psychology: Developing learners. New Jersey: Merrill Prenticee Hall.

Roe, W. H. \& Drake, T. L. (1980). The principalship. London: Collier Macmillan.

Sallis, E. (1993). Total quality management in education. London: Kogan Page.

Woolfolk, A. (2007). Educational psychology. New York, NY: Pearson.

Yin, R. K. (2009). Case study research: Design and method $\left(4^{\text {th }} \mathrm{ed}\right)$. Thousand Oaks, CA: Sage. 